\title{
TECHNOLOGY, CHEMISTRY AND BIOACTIVE PROPERTIES OF LARGE CARDAMOM (AMOMUM SUBULATUM ROXB.): AN OVERVIEW
}

\author{
Nawaraj Gautam ${ }^{1,2^{*}}$, Rewati Raman Bhattarai ${ }^{3}$, Bal Kumari Sharma Khanal ${ }^{4}$ and Prakash $\mathrm{Oli}^{5}$ \\ ${ }^{1}$ Faculty of Mathematics and Natural Science, University of Bergen, NO - 5020 Bergen, Norway. \\ ${ }^{2}$ National Institute of Nutrition and Seafood Research, Nordnes 5817, Bergen, Norway \\ ${ }^{3}$ Tribhuvan University, Central Campus of Technology, Hattisar, Dharan, Nepal. \\ ${ }^{4}$ School of Agriculture and Food Science, The University of Queensland, St 6 Lucia, Qld 4072, Australia \\ ${ }^{5}$ School of Agricultural \& Wine Sciences, Charles Sturt University, Wagga Wagga, Australia.
}

"Corresponding author's email: nawaraj90@gmail.com

\begin{abstract}
Large cardamom (Amomum subulatum Roxb.) is an aromatic and medicinal spice native to Eastern Himalayas belonging to the family Zingiberaceae. It is used as flavoring and preservative to different types of coffee, liquors, confections, beverages and tobacco. Volatile oil (2-4\%) is the principal aroma-giving compound in large cardamom and 1,8- cineole is the major active compound after compound, in an extent 60 to $80 \%$ of the total volatile oil. Alcohol and aqueous extract of large cardamom have been reported to contain allopathic, analgesic, anti-inflammatory, antimicrobial, antioxidant, antiulcer, cardio-adaptogenic and hypolipidaemic activities. Large cardamom and its powder, oleoresin and essential oils have many culinary and therapeutic uses. Objectives of this review is to give short overview on the processing technology, chemistry, bioactivity and uses of large cardamom and its components.
\end{abstract}

Keywords: Large cardamom; production; capsules; 1,8- cineole; bioactivity; uses

\section{Introduction}

Large cardamom (Amomum subulatom Roxburgh) is one of the popular spices that comes under the family Zingiberaceae. Origin of this spice is vivid but some author reported Eastern Himalayas region (Sharma et al., 2000) as its origin where wild species are still located. Large cardamom is also called black cardamom (Chempakam and Sindhu, 2008). The major producers of this spice are Nepal (52\%), India (37\%) and Bhutan (11\%) (Pothula and Singh, 2013) of total world production per annum. Large cardamom is a tall, perennial, evergreen, herbaceous monocot plant (Gopal et al., 2012). Height of this plant ranges from 1.5-3.0 m (Bisht et al., 2011) and leaves are found at the upper portion of the stem. The rhizomes are off dull red color and flower buds protrude from the base of the rhizome. Spring is the flowering season for large cardamom flowers. The peduncle is short and the buds encased in tight red bracts. Individual flowers remain open for three days and more. At the same time, new ones open successively. The inflorescence remains intact with flower for over a month (Sharma et al., 2000). The plants are usually grown on moist and shady parts of mountain streams and hilly slopes at an altitude of 765 to $1675 \mathrm{~m}$ above the sea level
(Gopal et al., 2012). It is climate dependent crop; best production is between temperature of $4-20^{\circ} \mathrm{C}$, annual rainfall of 2000-2500 mm and more than $90 \%$ humidity (NSCDP, 2009). The fruit is anterio-posteriorly flattened, having 15-20 irregular, dentate-undulate wings which extend from the apex to downward for two-thirds of its length (Gopal et al., 2012). The ripened fruit is trilocular, reddish brown, and contains dark pink seeded capsules (Hussain et al., 2009).

Capsules of large cardamom are held together inside the spike with viscous sugary pulp and are $20-25 \mathrm{~mm}$ long and oval to globular in shape (Thomas et al., 2009). The plant matures during the third year of its growth (Gopal et al., 2012) and harvesting is usually carried out during September to November, depending on the variety of plant and altitude of the plantation place (Spices Board, 2001). Small (true) cardamom, known as the 'Queen of Spices' is expensive and considered as one of the best spices in terms of quality (Chomchalow, 1996). Large cardamom is often used as a substitute of small cardamom, Elettaria cardamoтиm, in industrial products for flavoring of food (Joshi et al., 2013). The method of harvesting and curing 
(heaping) the cobs before stripping in the traditional method employ locally made wood fired curing house for drying. However, there are some improved methods suggested to retain the quality of produce (Rao et al., 2001). The major fragrance compound of the large cardamom is essential oil which mostly contains 1,8-cineole and it contributes pungent aroma. On the other hand, terpenyl acetate (component of fragrance) contributes the pleasant and cardamom like aroma (Chempakam and Sindhu, 2008). Color of large cardamom is mainly due to the presence of two pinkish-red pigments namely the cyanidin 3-glucoside and cyaniding-3,5-diglucoside (Naik et al., 2004).

In general, large cardamom is valued for its acceptable taste, flavor and aroma (Chempakam and Sindhu, 2008). It has been used as a spice and condiment since antiquity (Bhandari et al., 2013). The seeds of large cardamom have been used to flavor food, confections, beverages and liquids (Singh et al., 2008). Furthermore, it has been used as an insecticide as well (Satyal et al., 2012). Its usage in Ayurvedic is well known from prehistoric time. Cardamom have reported to posses valuable properties like allopathic, analgesic, anti-inflammatory, antimicrobial, antioxidant, antiulcer, cardio-adaptogen and hypolipidaemic activities. Therefore, large cardamom is highly valued spice and needs research on production, composition, uses and many more. Objectives of this review is to provide overview on the processing technology, chemistry, bioactivity and uses of large cardamom and its components and discuss on some lagging aspects.

\section{Production}

Total world production of large cardamom is about 12,278.20 MT (Pothula and Singh, 2013). Nepal is a world's top producer of large cardamom (Avasthe et al., 2011; Pothula and Singh, 2013; Kafle, 2013). Currently, its commercial cultivation spreads over 37 districts of Nepal (NSCDP, 2009; MOAC, 2010; Chaudhary et al., 2015). The Eastern development region of Nepal specifically accounts for around $97 \%$ of the total national production. The four major districts (Taplejung, Ilam, Sankhuwasabha and Panchthar) accounts for $81 \%$ of the national production (MOAC, 2010) but most of them are producing in small scales (Khatiwada and Piya, 2009). The annual production in Nepal has been exceeding 6,600 Metric Ton (MT) and many local farmers persuade to increase its production every year (Adhikari and Sigdel, 2015).

Like in Nepal, large cardamom is one of the main cash crops in Sikkim and Darjeeling district of West Bengal, India (Pathak, 2008). Major numbers of cardamom holdings in Sikkim are smaller than 1-Hectare (ha) area and around $30 \%$ of total cultivators have 1-3 ha of cardamom holdings (Sharma et al., 2009). According to Pothula and Singh (2013), Sikkim is the major production area in India. The plantation area of this crop in other than Sikkim on Indian
Himalayan region comprises of 550 ha covering a total of 34,252 ha in India (Sharma et al., 2009) with an annual production of over 4,500 MT (Pathak, 2008).

Apart from Nepal, India and Bhutan; large cardamom is also cultivated, to some extent in some of the Southeast Asian countries such as Thailand, Indonesia, Laos (Naik et al., 2004) and China. Of them, Indonesia has recently emerged as the additional key producers (ACCESO, 2011).

\section{Varieties}

The local varieties of large cardamom found in Himalayan regions are Ramsey, Golsey, Chibesey, Dambersey, Sawney and Kantidar. Among them, Ramsey, Golsey and Chibesey are widely distributed in Nepal (Thapa, 1998). The most important varieties found in Sikkim (India) include Ramsey, Golsey, Sawney, Kopringery, Madhusay and Rhangbhang. Among these, only Ramsey, Golsey and Sawney are considered for commercial production as these cultivars are well suited to high altitudes and can be cultivated even in steep slopes (Harktkamp, 1993).

The varietal differences of cardamom described by Chempakam and Sindhu, (2008), are presented in Table 1. Other varieties includes Ramla, Chivey Ramsey, Garday Seto Ramsey, Ramnag, Seto Golsey, Slant Golsey, Red Sawney, Green Sawney, Mingley (Chempakam and Sindhu, 2008), Barlanga (Rao et al., 1993) Bebo, Boklok Tali, Jaker and Belak (Pathak, 2008). Sajina et al. (1997) indicated that large cardamom can be used to enhance micro-propagation from rhizome buds. The protocols standardized for micropropagation through direct regeneration, can be used for large-scale production of planting material. Scientists have identified some varieties of large cardamom, which seem to be significantly more tolerant to diseases than the other varieties (Rai, 2011) and research work is currently on progress.

\section{Diseases}

Large cardamom plant are affected by a number of diseases, most of which are of viral and fungal origin. Among fungal diseases, flower rot caused by Fusarium and Rhizoctonia sp., leaf streak caused by Pestalotiopsis royenae and wilt caused by Fusarium oxysporum are some well-known causes to damage crop yield (Sanghamitra, 2008). Two viral diseases, Chirkey and Foorkey in recent years (Pathak, 2008), have brought a great numbers of destruction. These diseases spread due to radical change in climate, inadequate rain in dry months and absence of good agricultural practices by the farmers. Some researcher (Sharma et al., 2009) and the local farmers reported that these two viral diseases are the major cause of declining in cardamom plantation and agronomic yield in cardamom producing countries. 
N. Gautam et al. (2016) Int J Appl Sci Biotechnol, Vol 4(2): 139-149

Table 1: Characteristics of different varieties of large cardamom

\begin{tabular}{|c|c|c|c|}
\hline Character/variety & Ramsey & Golsey & Sawney \\
\hline Altitude & High & Low to middle & Middle \\
\hline Cultivation extent (\%) & 60 & 30 & 7 \\
\hline Features & $\begin{array}{l}\text { Tall, vigorous wide } \\
\text { clump growth }\end{array}$ & $\begin{array}{l}\text { Less vigorous with erect } \\
\text { leafy stem bearing } \\
\text { stout upright leaves, } \\
\text { clumps medium }\end{array}$ & $\begin{array}{l}\text { Tall, vigorous, } \\
\text { bent downwards }\end{array}$ \\
\hline Stem color & $\begin{array}{l}\text { Maroonish with dense } \\
\text { foliage }\end{array}$ & Greenish to marronish & $\begin{array}{l}\text { Pinkish with dark } \\
\text { green foliage }\end{array}$ \\
\hline Flowers & $\begin{array}{l}\text { Yellowish and small, } \\
\text { corolla tip with pink } \\
\text { tinge at base }\end{array}$ & Yellowish-orange & $\begin{array}{l}\text { Yellowish with pink } \\
\text { tinge as base of corolla }\end{array}$ \\
\hline Capsules & $\begin{array}{l}\text { Smaller } \\
\text { (16-30 seeds) }\end{array}$ & $\begin{array}{l}\text { Bold to round } \\
\text { (40-50 seeds) }\end{array}$ & $\begin{array}{l}\text { Medium bold } \\
\text { (30-40 seeds) }\end{array}$ \\
\hline Essential oil (\%) & $1.0-8.0$ & $2.3-5.0$ & $1.8-2.5$ \\
\hline Shade requirement & Deep shade & Less shade & $\begin{array}{l}\text { Moderate to deep } \\
\text { shade }\end{array}$ \\
\hline Disease susceptibility & $\begin{array}{l}\text { Susceptibility to } \\
\text { Chirkey } \\
\text { and Foorkey at lower } \\
\text { altitudes }\end{array}$ & $\begin{array}{l}\text { Tolerant to Chirkey and } \\
\text { Foorkey but susceptible } \\
\text { to leaf spots }\end{array}$ & $\begin{array}{l}\text { Suspectible to viral } \\
\text { diseases }\end{array}$ \\
\hline
\end{tabular}

Source: Chempakam and Sindhu, (2008)

\section{Chirkey}

Major cause for the declining large cardamom productions in Nepal and India is associated with disease named Chirkey. This disease is characterized by mosaic appearance and pale streak on leaves (Sanghamitra, 2008). Those streaks turn the plant to pale brown and then plant will dry and wither. This will lead to extensive reduction in flowering of plant. Transmission of this disease is caused by mechanical sap inoculation and by aphid, Rhopalosiphum maidis Fitch (Varadarasan and Biswas, 2002). Growth and yield of the infected plants gradually decline and ultimately leads to death of the plant (Pathak, 2008).

\section{Foorkey}

Foorkey is another major disease of large cardamom characterized by excessive sprouting and formation of bushy dwarf clumps at the base of mother plants, which gradually leads to death (Pathak, 2008). Numerous small tillers also appear at the base of affected plants, which becomes stunted and failure to give any production. The spikes/inflorescence is transformed into leafy vegetative parts and fruit formation is suppressed. The primary spread of disease from one area to another is through infected rhizomes and further spread within a plantation by aphids (Raychaudhuri and Chatterjee, 1958). Nano virus is associated with foorkey (Mandal et al., 2004) and the aphid, Micromyzus kalimpongensis is a transmitting vector for virus from the diseased to a healthy plant thereby leading to spread of the disease (Adhikari and Sigdel, 2015). The

budget for the improvement on treatment and control over diseases is very high and hence not significantly noticeable to overcome the amount of loss because of foorkey (Mandal et al., 2004).

\section{Post-harvest technology \\ Harvesting}

The yield starts from third year onward after planting (Kafle, 2013). Harvesting usually depends on the altitudes and cultivars and the fruits are harvested when the capsules are fully matured, usually during September to November (Spices Board, 2001). Harvesting at the correct stage of maturity produces high quality cardamom capsules (Ali, 2007). Brown color in the seeds of topmost capsule indicates full maturity of the capsule. When the topmost capsule is fully matured, the spike-bearing shoots are cut at $45 \mathrm{~cm}$ height and left for another 10-15 days to ensure maturity of all the capsules (Pathak, 2008). Spikes are harvested using mechanical utensils e.g. knife (Kafle, 2013). The harvested spikes are stored for 2-3 days after harvesting in order to separate capsules easily (Spices Board, 2001). Separation of capsules from spikes is perform manually, and no device has been used for this operation so far. The separated capsules are cleaned manually before curing (Pothula and Singh, 2013) to remove other plant materials. There are no modern sophisticated or automated machineries developed or implemented yet in large cardamom producing region of Himalayas. 


\section{Curing}

Curing is one of the important steps to determine the quality of large cardamom (Mande et al., 1999; Rao et al., 2001). Curing is normally associated with equilibration of color, moisture and ripeness. Fresh large-cardamom capsules contain about 70 to $80 \%$ moisture (on wet basis) (Mande et al., 1999), depending upon the maturity levels of capsules at the time of harvest. To achieve optimum moisture level and other quality-defining factor, the spikes with ripened capsules are harvested and heaped (cured) for 2-3 days (Oli, 2011). After heaping, capsules are stripped off from the spikes, cleaned and subjected to drying (Oli, 2011).

\section{Drying}

Cardamom is dried below $10 \%$ (wet basis) moisture content for the safe storage level and marketing of cardamom, (Mande et al., 1999). Drying is mostly achieved by traditional wood-fired dryers, which are built in the orchard. However, this traditional process causes blackening of the capsules and gives smoky flavor (Oli, 2011). In current scenario, some improved dryers have been also introduced but their use is limited. Very rare use of improved dryers is mostly associated with economy and availability of dryers to the local level. One reason to prefer traditional method over recently developed method is lack of adequate farmers' awareness on the quality degradations and processing loss of produce by traditional dryers. Furthermore, lack of farmers' knowledge on the operation of improved dryers is also another determining factor.

\section{Traditional method}

In traditional method of drying, the fresh cardamom capsules are dried in bhatti, a locally made curing house (Rao et al., 2001). Capsules are spread uniformly in a thick layer of $25-30 \mathrm{~cm}$ on bamboo mat placed over the frames of wood firing pit. Capsules are then dried by the combined effect of heat and smoke generated by the burning wood. This process takes about 24 to 28 hours and frequent racking is made to get uniform drying. After uniform drying, the capsules are rubbed against the rough surface in order to remove the tail (Tamang, 2000; Oli, 2011). The quality of large cardamom capsules cured in traditional bhattis is poor and they have a dark brown color with smoky flavor. There is a production of large quantity of charred, cracked capsules having less volatile oil in traditionally cured capsules. However, no scientific knowledge is required to build these kind of traditional bhattis. In the villages of producing areas, building, operation and management cost of bhattis is low and they are mostly constructed from locally available materials (Singh et al., 1989).

\section{Improved method of drying}

In the improved method, cured capsules are dried into two stages, at $60^{\circ} \mathrm{C}$ and $55^{\circ} \mathrm{C}$ respectively to get the desired moisture content (approx. 10-12\%) (Naik et al., 2000). The content is then cooled, cleaned, tails are removed and capsules are graded according to their size. Those capsules are packed in jute bags (waterproof lined with polythene) and stored in dry places (Oli, 2011).

Traditional bhattis are improved for more efficient and effective drying, where heating is performed indirectly through hot air and smoke is released outwards. Due to use of heat in the absence of smoke in improved dryers, they give more natural color and better quality product than traditional method (Oli, 2011). Department of food technology and quality control (DFTQC), Nepal has developed six drum dryer containing two sections- firing and drying sections (Oli, 2011) for more effective drying of cardamom capsules. These sections are enclosed in a wall made from stone and mud and the whole assembly is kept under enclosed roofed structure. Capacity of this dryer varies from $360 \mathrm{~kg}$ to $400 \mathrm{~kg}$ of fresh cardamom and the drying time is reported to have $24 \mathrm{~h}$ (Oli, 2011).

Another modified dryer is made by Tata Energy Research Institute, modification is based on gasifier system. It consist an updraft-type biomass gasifier connected to a traditional bhatti (Pothula and Singh, 2013). In this system, the firewood is converted into producer gas first and the gas is burnt below the cardamom bed to generate clean flue gases required for drying. In such dryer, the thermal efficiency is high, the producer gas combustion is clean and the cardamom bed is not exposed to smoke (Oli, 2011). This helps in producing dried capsules with natural color and greater volatile oil content (Oli, 2011). Pothula and Singh, (2013) have mentioned that the better quality of dried capsules were produced by improved dryer than that of capsules dried in traditional bhatti.

One modified drier with several wooden trays (containing the wire-mesh base) in which improvement is made on flue pipe curing house (Rao et al., 2001). The fresh cardamom capsules are spread over trays, where flue gas obtained through burning the firewood in the furnace, is supplied in the curing house through the flue pipes. This unit operates on the principle of space heating. Surrounding room air is heated through pipe by natural convection and radiation (Rao et al., 2001).

Pothula and Singh, (2013) reported another dryer containing mechanical trolley system operated by diesel or electricity. This curing system consists of a blower, a heating unit, and a multi-tray curing chamber, similar to a mechanical cabinet tray dryer. This system works effectively and produces high quality capsules. Its capacity is $600 \mathrm{~kg}$ and curing time is 12 hours. Another dryer having indirect heat curing system (Pothula and Singh, 2013) has also reported and is called the rocket stove dryer, which has been introduced as part of a Netherlands Development Organization initiative in Nepal. This flue-gas-based system produces less smoke and is reported to produce high-quality capsules (Stoep, 2010). There are several reports of curing systems developed in India by research institute, G.B. Pant Institute of Himalayan Environment and the Development 
and Central Food Technological Research Institute in Mysore (Pothula and Singh, 2013), but none are in use by farmers so far. These dryer are not cost effective as compared to traditional cured capsules dryers. Hence, use of modified dryer is very rare.

\section{Tail removing}

The cardamom capsule has a tail and capsules without the tail get a higher price. Generally, tails are removed with a scissor. However, it adds labor cost. The tail portion can be removed easily by rubbing capsules on wire mesh if the cardamom is dried well (Mande et al., 1999; Pathak, 2008). No sophisticated and modern method or machine are devised till the date to remove tails from the cardamom capsules. Cardamom polisher is under evaluation in Sikkim, India for possible use as a tail-cutting machine. Capsules without tail and with intact tail both have different prices on market and graded as two different categories (Pothula and Singh, 2013). These tails are byproducts and utilized on making agarbathi (incense sticks) (Chhetri et al., 2013). Apart from this, tails are also used as a source of fire energy with wood during curing process. There would be other possibilities to utilize these byproducts for the manufacturing different marketable products such as manure, fire starter, floor cleaner etc. in the future. Additionally, these byproducts might be used as an alternative source of cooking energy in traditional households. Hence, comprehensive research and study are recommended to utilize the byproducts in effective and efficient way for the economic and environmental perspective.

\section{Grading}

Cardamom is usually graded by their color and size. Dark colored with larger sized capsule is considered as a higher grade cardamom (Ali, 2007). Commercially, finished large cardamom capsules are graded from bigger to smaller capsules and capsules with or without tail (Sharma et al., 2009). Manual grading is widely used method for sorting based on size and color. Mechanical grading machines are also popular and manually operated sieves are used only in Nepal (Oli, 2011). Quality grading is not achieved on a local farmer level. Generally, labor cost in large cardamom producing region of South and South-East Asia are relatively low, so grading in whole seller and stocking company are intensively labor based.

\section{Packaging}

Cured hot capsules are first placed in bags, cooled and then sealed, which are stored on wooden platform to avoid contact with environmental moisture (Pothula and Singh, 2013). There are no recommended specialized packaging and handling systems for large cardamom. Generally, dried capsules are packaged in polythene-lined jute bags (Pothula and Singh, 2013) on different sizes based on the market demand. Their common size ranged from 40 to $100 \mathrm{Kg}$ (Kafle, 2013). The sealers machines can be used to seal the bags (Ali, 2007). One of the major loss associated with packaging and storage loss is by insects. The moisture content of capsules is around $10-13 \%$, which is ideal for the growth of insects (Naik et al., 2005). Fumigants like methyl bromide $(0.016 \mathrm{~kg} / \mathrm{m} 3)$, phosphine $(0.0015 \mathrm{~kg} / \mathrm{m} 3)$, and ethyl formate $(0.30 \mathrm{~kg} / \mathrm{m} 3)$ are recommended to control insects growing on dried capsules without interfering capsules' quality (Naik et al., 2005).

\section{Chemical composition}

Composition of large cardamom differs with variety and age of cardamom. Likewise, it also varies with the region and climate where it is cultivated (Chempakam and Sindhu, 2008). Dried fruit of large cardamom generally contains volatile oil $2.80-4 \%$, protein $6 \%$, starch $43 \%$, total ether extract $5 \%$ and total ash $4 \%$ (Madhusoodanan and Rao, 2001; Oli, 2011). Similarly, seeds of large cardamom contain moisture $8.5 \%$, protein $6 \%$, volatile oil $2.8 \%$, crude fiber $22 \%$, starch $43.2 \%$, ether extract $5.3 \%$ and alcohol extract 7\% (Shankaracharya et al., 1990). Additionally, 100 $\mathrm{g}$ of large cardamom seeds contains $666.6 \mathrm{mg}$ calcium, $412.5 \mathrm{mg}$ magnesium, $61 \mathrm{mg}$ phosphorous and 14.4 parts per million fluoride (Bhandari et al., 2013). It is well-known that large cardamoms are rich in active components that are responsible for its unique flavour and tastes. These bioactive components are mainly associated with aesthetic quality and ultimately the quality and cost. Essential oil and oleoresin are most important chemical constituents of this Himalayan spice (Yadav, 2013).

\section{Essential oil and Oleoresin}

Some studies reported that 1,8 -Cineole $(77.4 \%$ of total essential oil) (Ali et al., 2008; Singh et al., 2008; Satyal et al., 2012) is the dominant component of essential oil in large cardamom fruits. The fruit also contained $\beta$-myrcene $(5 \%)$, $\alpha$-terpineol (4.9\%), hexanoic acid (3.0\%), toluene $(2.4 \%)$, t-caryophyllene (2.3\%) and terpinen-4-ol (2.3\%) (Ali et al., 2008). Smaller amounts of formic acid, $\alpha$ - thujene, butanoic acid, decatriene and caryophyllene oxide are also reported (Ali et al., 2008). More than seventy compounds are identified in the seed oil and sixty-four in the rind oil of large cardamom (Satyal et al., 2012). Both seed and rind oils are dominated by 1,8 - cineole $(60.8 \%$ and $39.0 \%$ on seed and rind oil respectively). Moreover, essential oils contained $\alpha$-pinene $(6.4 \%$ and $4.8 \%), \beta$-pinene $(8.3 \%$ and $17.7 \%), \alpha$-terpineol $(9.8 \%$ and $12.3 \%)$, and terpinen-4-ol (3.4\% and $3.2 \%$ ) and Spathulenol (3.4\%) (Satyal et al., 2012).

The major components of oleoresin are 1,8-cineole; 5(hydroxymethyl)-2-furaldehyde; $\beta$-sitosterol; $\alpha$-terpineol; 2,3-dihydrobenzofuran (coumaran); terpinen-4-ol; eugenol; trans-nerolidol; n-heptacosane and n-nonacosane (Singh et al., 2008). The yield and chemical composition of oleoresin is affected by the production conditions and nature of the solvent used for extraction (Singh et al., 2008). 


\section{Chemistry of volatiles}

Components of volatile oil are the major aroma driving compound present in large cardamom. Steam distillation of the crushed seeds gives dark brown oil $(2.5 \%)$ with a cineollike aroma (Gopal et al., 2012). The highest level of volatile oil content was recorded on Golsey Dwarf variety amounting $3.32 \%$, whereas the lowest on White Ramna variety amounting $1.95 \%$ (Chempakam and Sindhu, 2008).

The pungency in large cardamom is attributed to high content of cineole, while terpenyl acetate contributes the pleasant aroma (Chempakam and Sindhu, 2008). Kikuzaki et al. (2001) isolated protocatechualdehyde, 1,7-bis (3,4dihydroxyphenyl) hepta-4E, 6E-dien-3-one, protocatechuic acid, and 2,3,7-trihydroxy-5-(3,4-dihydroxy-E-styryl)6,7,8,9-tetrahydro-5H-benzocycloheptane from the cardamom and reported that these aforementioned compounds were responsible for its unique pungency and fragrance. Gopal et al. (2012) reported that seeds accommodate cardamonin (2'.4'-dihydroxy-6'methoxyalcone) and alpinetin (7-hydroxy-5methoxyflavanone) and glycosides viz., petunidin 3,5diglucoside, leucocyanidin-3-O- $\beta$-D-glucopyranoside and a new aurone glycoside subulin, whose structure was established as 6,3',4',5'-tetrahydroxy-4-methoxyaurone-6O- $\alpha$-L-rhamnopyranosyl (1-4)- $\beta$-D glucopyranoside.

Apart from aforementioned compounds, there are nonvolaitle pigments also, which makes large cardamom chemistry unique on its own. Methanolic $\mathrm{HCl}$ extraction of fresh large cardamom yielded deep pinkish (cyanidin 3glucoside) and red (cyanidin 3, 5-diglucoside) pigments at the ratio of 1:2 (Naik et al., 2004). There is a need of extensive medical or chemical study to get exact understanding on benefits of these pigments and other nonvolatile components

\section{Bioactivity}

Large cardamom has been recognized for its wide range of physiological and pharmacological properties. The essential oil present in large cardamom has a typical characteristic flavor and possesses medicinal properties like stimulant, stomachic, alexipharmic and astringent. For this reason, this species has been used for the treatment of indigestion, vomiting, biliousness, abdominal pains and rectal diseases (Bisht et al., 2011).

The ethanolic and aqueous extract of large cardamom with a dose of $100 \mathrm{mg} / \mathrm{ml}$ and $200 \mathrm{mg} / \mathrm{ml}$ respectively showed anti-inflammatory activity (Alam et al., 2011). The spice is used mostly to treat infections in teeth and gums, throat troubles, congestion of lungs and pulmonary tuberculosis, inflammation of eyelids and also digestive disorders (Chempakam and Sindhu, 2008). Seed oil showed notable inhibition of germination in both lettuce (Lactuca sativa) and perennial ryegrass (Lolium perenne) seeds (Satyal et $a l ., 2012$ ) and this phytotoxicity has been attributed to high level of 1,8-cineole and $\alpha$-terpineol (Satyal et al., 2012). Furthermore, methanolic extract of seeds of A. subulatum at higher dose (more than $100 \mathrm{mg} / \mathrm{kg}$ ) and ethyl extract (above $200 \mathrm{mg} / \mathrm{kg}$ ) demonstrated remarkable analgesic effect (Shukla et al., 2010). This spice has been used since prehistoric time as antidote for scorpion and snake venom (Chempakam and Sindhu, 2008). However, there is no clear scientific evidence and safety precautions be adapted if extracts are used to replace the drugs.

\section{Antimicrobial activity}

Large cardamom has a wide variety of secondary metabolites such as tannins, alkaloids and flavonoids, some of these metabolites are believed to have antimicrobial properties. Petroleum ether extracts of large cardamom showed antimicrobial against Staphylococcus aureus, Escherichia coli, Pseudomonas aeruginosa (Kumar et al., 2010; Satyal et al., 2012) and Bacillus cereus (Satyal et al., 2012). Similarly, the acetonic, methanolic and ethanolic extracts (Hussain et al., 2011) of A. subulatum showed antimicrobial inhibitory activity against two bacteria causing dental caries, Streptococcus mutans and S. aureus; and two fungi Candida albicans and Saccharomyces cerevisiae (Aneja and Joshi, 2009). Antimicrobial activities against some bacteria and fungi are presented in Table 2 . Role of essential oil (from seeds) against various keratinophilic and dermophytic fungi (Jain and Agarwal, 1976) are not limited but they are believed to have much broader antifungal spectrum as discussed by Singh et al. (2008). Hence, it is necessary to explore and conduct study in the future regarding "broad spectrum fungal inhibition" property of essential oils' compounds from large cardamom.

\section{Antioxidant and scavenging activity}

The 1,8-cineole, alphaterpineol, protocatechualdehyde, protocatechuic acid extracted from seeds have antioxidant property against lipid peroxidation (Kikuzaki et al., 2001; Hafidh et al., 2009)) and have much potential health benefits (Jessie and Krishnakantha, 2005). These aforementioned or some other active components from seed have been associated with antioxidant role in hepatic, cardiac antioxidant enzymes (Verma et al., 2010) and activate other antioxidant enzymes as well (Dhuley, 1999). High level of phenolic compounds (Hafidh et al., 2009) present in essential oil are believed to be associated with significant activities on antioxidant assays (Singh et al., 2008). Moreover, these polyphenols content are reported to have strong reducing and inhibiting characteristics against lipid peroxidation in rat liver homogenate (Yadav and Bhatnagar, 2007). Eventually, those polyphenols will be working as superoxide radical scavenging compounds (Yadav and Bhatnagar, 2007). 
Table 2: Biological activities of Amomum subulatum essential oils

\begin{tabular}{|c|c|c|}
\hline Bioassay & Seed oil & Rind oil \\
\hline \multicolumn{3}{|l|}{ Antimicrobial (MIC, $\mu \mathrm{g} / \mathrm{mL}$ ) } \\
\hline Bacillus cereus & 625 & 313 \\
\hline Staphylococcus aureus & 313 & 625 \\
\hline Escherichia coli & 625 & 1250 \\
\hline Pseudomonas aeruginosa & 625 & 1250 \\
\hline Aspergillus niger & 313 & 19.5 \\
\hline C. elegans nematocidal $\left(\mathrm{LC}_{50}, \mu \mathrm{g} / \mathrm{mL}\right)$ & 341 & not tested \\
\hline \multicolumn{3}{|l|}{ Insecticidal $\left(\mathrm{LC}_{50}, \mu \mathrm{g} / \mathrm{mL}\right)$} \\
\hline Drosophila melanogaster & 441 & 493 \\
\hline Solenopsis invicta $\times$ richter $i$ & 1500 & 1150 \\
\hline
\end{tabular}
Source: Satyal et al. (2012)

Table 3: Specifications of large cardamom in Nepal and India

\begin{tabular}{|c|c|c|}
\hline Parameters & Nepal & India \\
\hline \multicolumn{3}{|l|}{ Capsules } \\
\hline Extraneous matter & Not more than $5 \%$ by weight & Not more than $1 \%$ by weight \\
\hline Volatile oil \% (ml/100g) & Not less than $1 \%$ by weight & Not less than $1 \%$ by weight \\
\hline Color and flavor & Natural and characteristic & Natural and free from added colors \\
\hline Moisture & n........ & Not more than $14 \%$ by weight \\
\hline Insect damaged capsules & $\ldots \ldots \ldots \ldots$ & Not more than $5 \%$ by weight \\
\hline \multicolumn{3}{|l|}{ Seeds } \\
\hline Extraneous matter & Not more than $2 \%$ by weight & Not more than $2 \%$ by weight \\
\hline Volatile oil \% (ml/100g) & Not less than $1 \%$ by weight & Not more than $2 \%$ by weight \\
\hline Color and flavor & Natural and characteristic & Natural and characteristic \\
\hline Moisture & n....... & Not more than $13 \%$ by weight \\
\hline Insect damaged capsules & $\ldots \ldots \ldots \ldots$ & Not more than $2 \%$ by weight \\
\hline Total ash & $\ldots \ldots \ldots \ldots$ & Not more than $5 \%$ by weight \\
\hline Ash insoluble ash & $\ldots \ldots \ldots \ldots$ & Not more than $2 \%$ by weight \\
\hline Moulds and insects & $\ldots \ldots \ldots \ldots$ & Absent \\
\hline \multicolumn{3}{|l|}{ Powder } \\
\hline Moisture & Not more than $15 \%$ by weight & Not more than $11 \%$ by weight \\
\hline Total ash & Not more than $8 \%$ by weight & Not more than $8 \%$ by weight \\
\hline Volatile oil \% (ml/100g) & Not less than $1 \%$ by weight & Not less than $1 \%$ by weight \\
\hline Ash insoluble in dilute $\mathrm{HCl}$ & Not more than $3 \%$ by weight & Not more than $2 \%$ by weight \\
\hline Color and flavor & Natural and characteristic & Natural and characteristic \\
\hline
\end{tabular}

Source: (Nepal Food Standard, 2006; Oli, 2011; Chempakam and Sindhu, 2008)

\section{Other activities}

Crude methanolic extract of the fruits shows anti-ulcer activity in albino rats (Jafri et al., 2001). Similarly, methanolic fraction, petrol soluble fraction, ethyl acetate soluble fraction and ethyl acetate soluble fraction have reported to play significant role against ethanol induced ulcer (Sen et al., 2009; Farah et al., 2005), lower aspirin induced gastric ulcer by $60 \%$ (Farah et al., 2005), possesses hepato-protective activity against ethanol-induced liver damage in rats (Parmar et al., 2009) and protect acute or severe stress induced myocardial damages respectively (Verma et al., 2010). It is useful in treatment for patients with Ischemic Heart Disease (IHD) (Bisht et al., 2011). Therefore, regular consumption of large cardamom can be associated with many health benefits. Benefits and usefulness are discussed on lower section of this paper on broader perspectives.

\section{Uses}

According to Chempakam and Sindhu (2008), the quality and uses of large cardamom is based mainly on appearance, visual superiority (particularly: color, uniformity of size, shape, consistency, texture) and flavor (influenced by the aromatic compounds). Nepal Food Standard (2006), Oli (2011) and Bureau of Indian Standards (Chempakam and 
Sindhu, 2008) have given specifications for capsules, seeds and powder of large cardamom which is shown in Table 3. It is believed that cleaned, sound, free from fungal growth or foreign material with bold and uniform sized cardamom capsules having dark pink colorations have high commercial values in the market (Mande et al., 1999). Cardamom seeds, whole or in powdered form, are used as one of the most valuable spices; often employed in the preparation of curry powder, pickles, sausages, cakes and confectionery. The powdered seeds are sometime supplied as a flavoring to coffee, liquors and tobacco. Traditionally, they are used for the culinary and therapeutic purposes. Perhaps, there could be other possible applications such as cosmetic and decorating products but advised for further studies.

\section{Culinary uses}

Large cardamom pods can be used as a whole or in split in some of the south Asian (mostly Nepalese and Indian) cuisines. It is incorporated in sweet dishes, drinks like punches and mulled wines, milk tea, curries, different rice dishes, pickles etc (Chempakam and Sindhu, 2008). Some people used to chew it as such habitually (like nuts). It is often used in Scandinavian bakeries (like in Danish pastries) and cardamom coffee (symbol of hospitality in Arab world) because cardamom is one of the popular spices in Arab world (ACCESO, 2011; Gopal et al., 2012). The small amount of cardamom on coffee cake also adds a tempting flavor. Taste of flans, rice puddings and porridges are much more enhanced by adding cardamoms (Gopal et al., 2012). Smoky grounded cardamom seeds are an optional ingredient in mixed preparations and spice masala mixtures. There is a literature (Chempakam and Sindhu, 2008) on cardamom flavored soda as well. All these culinary use envoys cardamom as a useful spice. There could be possibilities of introducing new drinks varieties such as cardamom flavored dairy products and cardamom flavored seafood items in near future.

\section{Therapeutic uses}

Large cardamom also possesses curative properties, and been one of the major spices which are mentioned in Ayurveda and Unani medicine (Chempakam and Sindhu, 2008). From pre-historic time, large cardamom seeds have been used to cure dyspnoea, cough, thirst, vomiting, disease of mouth, nausea, itching, indigestion, biliousness, abdominal pains and rectal diseases in local villages and cities (Gopal et al., 2012). Ayurveda experts prescribe large cardamom to inflammation of the eyelids, treat and prevent throat troubles, congestion of the lungs and pulmonary tuberculosis (Gopal et al., 2012). Medicinally, those seeds have diuretic, antidote for snake and scorpion venome, stimulant, stomachic, alexipharmic and astringent properties (Gopal et al., 2012). Cardamom capsules and seeds are used to treat gonorrhea, congestive jaundice, headache, and stomatitis and to control insects (Satyal et al., 2012) as shown previously on Table 2. Antioxidant properties of bioactive component are key players on therapeutic perspectives (Dorman and Deans, 2000; Cai et al., 2004). Antimicrobial properties of oleoresins and essential oils have been used as a preservative (Singh et al., 2009) for different types of juices and are free from hazardous harmful substances indicating their superiority to synthetic preservatives.

\section{Conclusions}

Large cardamom is a very popular commercially important aromatic spice, is highly preferred in many indigenous and other food cuisines especially in south Asia. Whole or powdered cardamom, essential oil and oleoresins have much wider applications in food cuisines and in pharmaceutical medicines. The processing methods and extraction conditions must be optimized for higher retention of bioactive compounds. Hence, development of commercial and advance process for the treatment and production systems and their possible allopathic and industrial applications are some of the major challenging issues. Many bioactive compounds are responsible for allelopathic, analgesic, anti-inflammatory, antimicrobial, antioxidant, antiulcer, cardio-adaptogen and hypolipidaemic properties. It is highly valued for its acceptable taste, flavor and aroma and also possesses curative properties as mentioned in the Ayurveda and Unani medicine. Very limited research has been carried out on clinical studies of bioactive components of large cardamom. Hence, this is challenging area for the scientists to explore its bioactive compounds. Additionally, there would be possibility of presence of other health beneficial compounds which are not identified yet. Recommendations is on intense and through research on large cardamom in upcoming days to identify the potential medicinal values. Additionally, agro-economic perspectives must be focused on market expansion and market values during large cardamom research and development.

\section{References}

ACCESO. (2011). "The world market for cardamom. Market Survey \#02". Produced for the USAID ACCESO Project. http://pdf.usaid.gov/pdf_docs/PA00KNZM.pdf (Jan. 10, 2015).

Adhikari PP and Sigdel K (2015) Activities of cardamom development center and DoA in large cardamom development. In: Chaudhary $\mathrm{R}$ and Vista SP (Eds.). Proceedings of the stakeholders consultation workshop on large cardamom development in Nepal. NARC publication serial no. 00225-135/2014/015. Nepal Agricultural Research Council, Nepal.

Alam K, Pathak D and Ansari SH (2011) Evaluation of AntiInflammatory activity of Amomium Subulatum fruit extract. Int J Pharma Sci Drug Res, 3(1): 35-37.

Ali SA (2007) “Cardamom Processing”. Practical action technical brief.

http://practicalaction.org/practicalanswers/product_info.p hp?manufacturers_id=17\&products_id=76 (Jan 10, 2015). 
Aneja KR and Joshi R (2009) Antimicrobial activity of Amomum subulatum and Elettaria cardamomum against dental carries causing microorganisms. Ethnobot Leaflets, 13: 840-849.

Avasthe RK, Singh KK and Tomar JMS (2011) Large cardamom (Amomum subulatum Roxb.) based agroforestry systems for production, resource conservation and livelihood security in the Sikkim Himalayas. Indian J Soil Conserv, 39(2): 155-160.

Bhandari AK, Bisht VK, Negi JS and Baunthiyal M (2013) 1, 8Cineole: A predominant component in the essential oil of large cardamom (Amomum subulatum Roxb.). J Med Plants Res, 7(26): 1957-1960.

Bisht VK, Negi JS, Bhandari AK and Sundriyal RC (2011) Amomum subulatum Roxb: Traditional, phytochemical and biological activities-An overview. African J Agric Res, 6(24): 5386-5390. DOI: 10.5897/AJAR11.745

Cai Y, Luo Q, Sun M and Corke H (2004) Antioxidant activity and phenolic compounds of 112 traditional Chinese medicinal plants associated with anticancer. Life Sci, 74(17): 2157-2184. DOI: 10.1016/j.lfs.2003.09.047

Chaudhary RN, Vista SP and Chaudhary R (2015) Overview of Research Effort, Challenges and Opportunities in Large Cardamom. In: Chaudhary, R. and Vista SP, (Eds.). Proceedings of the stakeholders consultation workshop on large cardamom development in Nepal. NARC publication serial no. 00225-135/2014/015. Nepal Agricultural Research Council, Nepal.

Chempakam B and Sindhu S (2008) Large Cardamom. In: Parthasarathy VA, Vhempakam B and Zachariah TJ (Eds.), Chemistry of Spices. CAB International, pp. 59-69. DOI: $10.1079 / 9781845934057.0059$

Chhetri P, Bhattarai NK, Gudade BA and Gupta U (2013) Reviewindigenous knowledge on large cardamom. Life Sci leafl, 7: 67-71.

Chomchalow N (1996) Spice Production in Asia - An Overview. Unpublished paper presented at the IBC's Asia Spice Markets '96 Conference, Singapore, May 27-28. p.5.

Dhuley JN (1999) Anti-oxidant effects of cinnamon (Cinnamomum verum) bark and greater cardamom (Amomum subulatum) seeds in rats fed high fat diet. Indian J Exp Biol 37(3): 238-242.

Dorman HJD and Deans SG (2000) Antimicrobial agents from plants: antibacterial activity of plant volatile oils. $J$ Appl Microbiol, $\quad 88(2)$ : $308-316$. DOI: $10.1046 /$ j.13652672.2000.00969.x

Farah AJ, Siddiqui A, Aslam M, Javed K and Jafri MA (2005) Antiulcerogenic activity of Elettaria cardamomum Maton. and Amomum subulatum Roxb. seeds. Indian J Tradit Know, 4(3): 298-302.

Gopal K, Baby C and Mohammed A (2012) Amomum Subulatum Roxb: An overview in all aspects. Int Res J Pharm, 3(7): 96-99.

Hartkamp AD (1993) Black Gold- A study on large cardamom in the Eastern Hills of Nepal. Report on a practical training,
Department of Agronomy, Department of Plant

Taxonomy, Wageningen Agricultural University, Nederland.

Hussain J, Khan AL, Rehman N, Zainullah, Khan F, Hussain ST and Shinwari ZK (2009) Proximate and nutrient investigations on selected medicinal plant species of Pakistan. Pakistan J Nutr, 8: 620-624. DOI: 10.3923/pjn.2009.620.624

Hussain T, Arshad M, Khan S, Hamid S and Qureshi MS (2011) In vitro screening of methanol plant extracts for their antibacterial activity. Pakistan J Botany 43(1): 531-538.

Jafri MA, Farah KJ and Singh S (2001) Evaluation of the gastric antiulcerogenic effect of large cardamom (fruits of Amomum subulatum Roxb.). J Ethnopharmocol, 75: 8994. DOI: $10.1016 / \mathrm{S} 0378-8741(00) 00398-6$

Jain PC and Agarwal SC (1976) Activity of some plants extracts against some keratinophilic species of Nannizzia. Ind. Drugs, 23(12): 25-26.

Jessie SW and Krishnakantha TP (2005) Inhibition of human platelet aggregation and membrane lipid peroxidation by food spice, saffron. Mol Cell Biochem, 278: 59-63. DOI: 10.1007/s11010-005-5155-9

Joshi R, Sharma P, Sharma V, Prasad R, Sud RK and Gulati A (2013) Analysis of the essential oil of large cardamom (Amomum subulatum Roxb.) growing in different agroclimatic zones of Himachal Pradesh, India. J Sci Food Agric, 93: 1303-1309.DOI: 10.1002/jsfa.5886

Joshi SC and Joshi V (2007) Effect of Amomum subulatum on oxidative stress and atherosclerosis in cholesterol fed rabbits. Pharmacol online, 1: 451-463.

Kafle B (2013) "Cardamom farming in Nepal". http://kaflebishal.blogspot.com/2013/03/cardamomfarming-in-nepal.html (Jan. 12, 2016).

Khatiwada PP and Piya S (2009) Status of large cardamom cultivation in the eastern hills of Nepal. In: Acharya UK, Adhikari NP, Sherchan DP, Yadav PK and Karki KB, (Eds.). Proceeding of Second National Workshop on Commercial Crops, 14-15 November, 2005. National Agriculture Research Institute, Nepal.

Kikuzaki H, Kawai Y and Nakatani N (2001) Diphenyl-2picrylhydrazyl radical-scavenging active compounds from greater cardamom (Amomum subulatum Roxb.). J Nutr Sci Vitaminol, 47(2): 167-171. DOI: 10.3177/jnsv.47.167

Kumar U, Kumar B, Bhandari A and Kumar Y (2010) Phytochemical investigation and comparison of antimicrobial screening of Clove and Cardamom. Int Jorunal Pharma Sci Res, 1(12): 138-147.

Madhusoodanan KJ and Rao YS (2001) Cardamom (large). Indian Cardamom Research Institute, Woodhead publishing Ltd., Kerala. DOI: 10.1533/9781855736450.134

Mandal B, Mandal S, Pun KB and Varma A (2004) First Report of Association of Nanovirus with Foorkey disease of Large cardamom in India. Plant dis, 88:428. DOI: 10.1094/PDIS.2004.88.4.428A 
Mande S, Kumar A and Kishore VVN (1999) A study of largecardamom curing chambers in Sikkim. Biomass Bioenergy, 16: 463-473. DOI: 10.1016/S09619534(99)00020-3

MOAC (2010) Summer Crop Nepal 2009/2010: Crop and Food Security Update. Ministry of Agriculture and Cooperatives, Government of Nepal and World Food Program, Nepal.

Naik HP, Balasubrahmanyam, N, Dhanaraj S and Gurudutt KN (2000) Packaging and storage studies in flue-cured large cardamom (Amomum subulatum Roxb.). J Food Sci Technol (Mysore), 37(6):577-581.

Naik JP, Jagan Mohan Rao L, Mohan Kumar TM and Sampathu SR (2004) Chemical composition of the volatile oil from the pericarp (husk) of large cardamom (Amomum subulatum Roxb.). Flavour Fragr J, 19(5): 441-444. DOI: 10.1002/ffj.1336

Naik JP, Mohan KTM, Sulochanamma G, Ramesh BS and Sampathu SR (2006) Studies on quality attributes of cultivars of large cardamom (Amomum subulatum Roxb.). J Food Sci Technol (Mysore), 43(3): 308-311.

Naik JP, Ramesh BS and Gurudutt KN (2005) Fumigation studies on cured large cardamom (Amomum subulatum Roxb.) capsules. J Food Sci Technol (India), 42(6):531-533.

Nepal Food Standard (2006) Standards for Spices and Condiments. DFTQC, Kathmandu, Nepal.

NSCDP (2009) Annual report of national spice crop development programme. National Spice Crop Development Programme, Government of Nepal, Ministry of Agriculture and Cooperative, Khumaltar, Kathmandu.

Oli P (2011) Post Harvest Technology of Tea, Coffee and Spices, First Ed. Lalitpur Valley College, Nepal.

Parmar MY, Shah P, Thakkar V and Gandhi TR (2009) Hepatoprotective activity of Amomum subulatum Roxb. against ethanol-induced liver damage. Int J Green Pharm, 3(3): 250-254. DOI: 10.4103/0973-8258.56286

Pathak A (2008) Cultivation of Large Cardamom in Sikkim. Ishani, Bimonthly J Mahatma Gandhi Ishani Foundation, 2(6): 1-9.

Pothula AK and Singh AI (2013) Postharvest Processing of Large Cardamom in the Eastern Himalaya. Mt Res Dev, 33(4): 453-462. DOI: 10.1659/MRD-JOURNAL-D-12-00069.1

Rai A (2011) "Fungus identified, Spices Board grapples with ways to fight it and resuscitate large cardamom production in Sikkim" http://sikkimnow.blogspot.com/2011/11/fungusidentified-spices-board-grapples.html (Feb. 1, 2016).

Rao VG, Mande S and Kishore VVN (2001) Study of drying characteristics of large-cardamom. Biomass Bioenergy, 20: 37-43. DOI: 10.1016/S0961-9534(00)00047-7

Rao YS, Gupta U, Anand K and Naidu R (1993) A note on large cardamom (Amomum subulatum Roxb.) germplasm collection. J Spices Aromatic Crops, 2: 77-80.

Raychaudhuri SP and Chatterjee SN (1958) A preliminary note on the occurrence of a new virus disease of the large cardamom (Amomum subulatum Roxb.), in Darjeeling Dist. In: Proceedings of Mycological Research Workers conference, ICAR, held at Shimla 20 -23 June 1958, pp. 174-176.

Sajina A, Mini PM, John CZ, Babu KN, Ravindran PN and Peter KV (1997) Micropropagation of large cardamom (Amomum subulatum Roxb.). J Spices Aromatic Crops, 6 (2): 145-148.

Sanghamitra V (2008) Partial characterization of the virus associated with foorkey disease of Large cardamom (Amomum subulatum Roxb.). Master's Thesis. Acharya Nagarjuna University, Guntur.

Satyal P, Dosokyb NS, Kincerb BL and Setzera WN (2012) Chemical Compositions and Biological Activities of Amomum subulatum Essential Oils from Nepal. Nat Prod Commun, 7 (9): 1233-1236.

Sen S, Chakraborty R, De B and Mazumder J (2009) Plants and phytochemicals for peptic ulcer: an overview. Pharmagonosy Rev, 3(6): 270-279.

Shankaracharya NB, Raghavan B, Abraham KO and Shankaranarayana ML (1990) Large cardamom chemistry, technology and uses. Spice India, 3(8):17-25.

Sharma E, Sharma R, Sharma G and Singh KK (2000) 'A Boon for Mountain Populations: Large Cardamom Farming in the Sikkim Himalaya'. Mt Res Dev, 20(20): 108-111. DOI: 10.1659/0276-4741(2000)020[0108:ABFMP]2.0.CO;2

Sharma G, Sharma R and Sharma E (2009) Traditional knowledge systems in large cardamom farming: biophysical and management diversity in Indian mountainous regions. Indian J Tradit Know, 8(1): 17-22.

Sharma R, Sharma G and Sharma E (2002) Energy efficiency of large cardamom grown under Himalayan alder and natural forest. Agroforestry Syst, 56(3): 233-239. DOI: 10.1023/A: 1021351626653

Shukla SH, Mistry HA, Patel VG and Jogi BV (2010) Pharmacognostical, preliminary phytochemical studies and analgesic activity of Amomum subulatum Roxb. Pharma Sci Monit, 1(1): 90-102.

Singh G, Kapoor IPS and Singh B (2009) Essential oil and oleoresins of cardamom (amomum subulatum roxb.) as natural food preservatives for sweet orange (citrus sinensis) juice. J Food Process Eng, 34: 1101-1113.

Singh G, Kapoor IPS, Singh B, Isidorov V and Szczepaniak L (2008) Chemistry, antifungal and antioxidant activities of cardamom (Amomum subulatum) essential oil and oleoresins. Int J Essential Oil Ther, 2: 29-40.

Singh KA, Rai RN, Patiram and Bhutia DT (1989) Large cardamom (Amomum subulatum Roxb) plantation - an age old agroforestry system in eastern Himalayas. Agroforestry Syst, 9(3):241-257. DOI: 10.1007/BF00141087

Spices Board (2001) Guidelines for Production of Organic Spices in India. Cochin, India: Spices Board. 
Stoep GAV (2010) Enhancing competitiveness of Nepal's large cardamom value chain. Kathmandu, Nepal: SNV Nederlands Development Organization.

Tamang PR (2000) Theoretical design of an appropriate large cardamom (Amomum Subulatum Roxb.) drier at farm level in Nepal. Dissertion, B.Tech. (Food), Central Campus of Technology, Hattisar, Dharan.

Thapa MB (1998) Nepalma alaichi bali, yesko bikashma bhayeka prayas, bartaman sthiti tatha sambhawana (in Nepalese). In: Thapa MB and Niraula GS (ed.) Proceeding of Seminar/Workshop on Cardamom Production, Research and Marketing. Ministry of Agriculture, Department of Agriculture, Cardamum Development Centre, Fikkal, Illam.

Thomas VP, Sabu M and Gupta U (2009) Taxonomic studies on cultivars of Amomum subulatum. Rheedea, 19: 25-36.
Varadarasan S and Biswas AK (2002) Large cardamom (Amomum subulatum Roxb.). In: Ravindran PN and Madhusoodanan KJ (ed.) Cardamom, The genus Elettaria. CRC Press, London: Taylor and Fracis Inc, pp. 299-329.

Verma SK, Rajeevan V, Bordia A and Jain V (2010) Greater cardamom (Amomum subulatum Roxb.) - A cardioadaptogen against physical stress. J Herb Med Toxicol, 4(2): 55-58.

Yadav AS and Bhatnagar D (2007) Modulatory effect of spice extracts on iron-induced lipid peroxidation in rat liver. Biofactors, 29: 147- 157. DOI: 10.1002/biof.552029205

Yadav S (2013) Cardamom cultivation, its effect in rural livelihoods and its importance in international market. MSc. Thesis. University of Nordland, Norway. 